\title{
Proceeding
}

Supplementary Issue: Spring Conferences of Sports Science. Costa Blanca Sports Science Week, 26-28 April 2018. Calpe. Alicante, Spain

\section{Social use of internet in adolescents: Relationship with cyberbullying and levels of physical activity}

\author{
FÁTIMA CHACÓN-BORREGO $1 \unlhd$, CAROLINA CASTAÑEDA-VÁZQUEZ1 ${ }^{1}$ JESÚS DEL POZO-CRUZ², \\ JUAN ANTONIO CORRAL-PERNIÁ ${ }^{1}$ \\ ${ }^{1}$ Research Group HUM-5071, Department of Physical Education and Sport, Faculty of Education Sciences, \\ University of Seville, Spain \\ ${ }^{2}$ Research Group CTS-972, Department of Physical Education and Sport, Faculty of Education Sciences, \\ University of Seville, Spain
}

\begin{abstract}
An unsuitable and abusive use of the Internet and the technologies that support it (e.g. mobile phones and computers) can be related to the appearance of different problems and risks during adolescence, such as addiction and cyberbullying (CB) (Armstrong et al., Saling, 2000; Carbonell et al., 2012; Tokunaga, 2010; Tsitsika et al., 2015). The objective of this research is to know about the use of social networks (SN) and communication applications, the degree of intrapersonal (IntraA) and interpersonal (InterA) addictions caused by the problematic Internet use, as well as the possible relations between dependence, CB and physical activity (PA) levels determined, in an objective manner, through the use of accelerometers. Results show that there is an IntraA of $M=2.21$ ( $S D=0.62$ ) and an InterA of $M=1.97(S D=0.53)$, as it is the need of continuously checking the SN and WhatsApp (WAPP), the use of the Internet as a way of escaping from problems and the withdrawal from other activities in order to being connected to the Internet for a longer period of time. There is a relation between the Internet addiction and CB but not between the different levels of PA performance and these variables. Key words: INTERPERSONAL RELATIONSHIP, INTRAPERSONAL RELATIONSHIP, ADDICTION, SOCIAL NETWORKING, SPORT, MOBILE PHONE.
\end{abstract}

Cite this article as:

Chacón-Borrego, F., Castañeda-Vázquez, C., Del Pozo-Cruz, J., \& Corral-Pernía, J. (2018). Social use of internet in adolescents: Relationship with cyberbullying and levels of physical activity. Journal of Human Sport and Exercise, 13(2proc), S209-S220. doi:https://doi.org/10.14198/jhse.2018.13.Proc2.05

Corresponding author. Department of Physical Education and Sport. Room 5.07, Faculty of Education Sciences. c/ Pirotecnia, s/n. CP. 41013 (Seville). Spain. https://orcid.org/0000-0002-1499-2552

E-mail: fchacon@us.es

Supplementary Issue: Spring Conferences of Sports Science. Costa Blanca Sports Science Week, 26-28 April 2018. Calpe. Alicante, Spain.

JOURNAL OF HUMAN SPORT \& EXERCISE ISSN 1988-5202

(c) Faculty of Education. University of Alicante

doi: 10.14198/jhse.2018.13.Proc2.05 


\section{INTRODUCTION}

The use of the Internet and social networks (SN) has increased in the last years among young people. According to the data of the National Statistics Institute (Instituto Nacional de Estadística. INE, 2017), 95.1\% of the young people between 10-15 years old are Internet users, which is facilitated by the wide accessibility to different electronic devices (e.g. tablets, computers and mobile phones) at these ages. From increasingly earlier ages children have their own smart phones with percentages that raise from $25 \%$ in 10 -year-old children, $75 \%$ in 12 -year-old, up to $94 \%$ at the age of 15 .

The Internet, in addition to having an educational use, is mainly a leisure and communication tool for $82.3 \%$ of the children, according to the data provided by the Childhood Observatory in Andalusia (Observatorio de la Infancia, 2010).

However, the unsuitable and abusive use of the Internet and technologies that support it (e.g. mobile phones and computers) can be related to the appearance of different problems and risks at all ages and especially among the youngest. According to results in many studies, adolescence is a period very susceptible to the appearance of problems associated with the Internet (Armstrong et al., Saling, 2000; Carbonell et al., 2012; Estévez et al., 2009; Gómez et al., 2014; Pichel, 2014; Tokunaga, 2010; Tsitsika et al., 2015).

Those online activities more often related to a problematic Internet use among teenagers are chats, WhatsApp (WAPP), SN, emails and online games (Carbonell et al., 2012; Giménez et al., 2017; Muñoz-Rivas et al., 2010). Data from the EU Kids Online European study (quoted in Garmendia et al., 2011) show that $97 \%$ of young people have a profile in a $\mathrm{SN}$.

This tool is very appealing to teenagers since it allows them to create communication nets with many people and keep contacts for long periods of time at any moment. At the same time, at these ages the fact of having a larger amount of online contacts provides them with a feeling of comfort (Kim and Lee, 2011). Nonetheless, it can become a problem according to the studies by Casas et al. (2013), Garmendia et al. (2011) and Tsai and Lin (2003).

Problems linked to the Internet use can be translated into the appearance of addictions (Carbonell et al., 2012; Echeburúa and Corral, 2010; Helguera, 2017; Labrador and Villadongos, 2010; Sánchez-Martínez and Otero, 2009; Ybarra and Mitchell, 2004), a higher risk of cyberbullying (CB) (Antoniadou et al., 2016; Dinev et al., 2008; Fernández and López-Hernáez, 2015; Fernández-Montalvo et al., 2015; Giménez et al., 2017; Kowalski et al., 2014; Ortega et al., 2013) and other ways of aggressive behaviour like cybergrooming and sexting. (Ortega et al., 2013).

Bernanuy et al. (2009) present as problems related to the Internet use the appearance of Intrapersonal (IntraA) and Interpersonal (InterA) conflicts that ultimately reveal symptoms similar to those of other addictions such as, the loss of control over its use, the need to increase the time of exposure to reach satisfaction, the withdrawal from other leisure activities like meeting friends or the performance of physical activity (PA), the appearance of conflicts with parents, hiding, a decrease in the academic performance, changes of behaviour associated with being deprived of access to their mobile devices and/or the Internet, irritability and insomnia (Aragón et al., 2016; Arora et al., 2014; Fernández-Montalvo et al., 2015; MuñozRivas et al., 2010). 
The highest risk of suffering CB in children and teenagers is related to behaviours on the Internet that increase their vulnerability due to overexposure, as those described by Bringué and Sádaba (2011), Fernández-Montalvo et al. (2015), Garaigordobil (2013), Helguera (2017) or Hinduja and Patchin (2009), for instance: making contact with people they do not know; arranging appointments with strangers; sharing personal information, photos, videos or passwords; lying about their age or physical appearance; sending or receiving offensive or insulting messages; and defaming or spreading rumours in order to cause harm.

There are few studies that have analysed the relationship between the physical-sport activity and the Internet use, which can be utilised to confirm whether, as stated by authors like Fernández-Montalvo et al. (2015) and Ortega-Ruiz et al. (2012), the unsuitable and abusive use of the Internet and electronic devices reduces and distances people from their leisure activities.

There is a confirmed relation between the abusive and unsuitable use of the Internet and a higher risk of addiction and $\mathrm{CB}$, but is there any relationship between these elements and the PA performed by teenagers?

The research by Kim at al. (2015) shows that young men with a problematic Internet use through mobile phones perform less PA than those with a more standard use. In young women, this type of unsuitable Internet use is related to a higher probability to being less active physically (Piguet et al., 2015). Besides, there is a higher use of the technologies and shorter time to perform PA in those teenagers with a higher tendency to boredom (Biolcati et al., 2018).

Conversely, studies which analyse the PA and its relationship to bullying (B) and $C B$ do not show conclusive data. In this sense, Chacón-Cuberos et al. (2015) and Zurita et al. (2018) do not find significant relationships between extracurricular sport practice, sport category and B. Only the study by Ortega et al. (2008) finds connections between a higher self-esteem of the sport factor in attacking children with respect to the victims of $B$ and $C B$.

This present research aims at: (i) analysing the Internet use as a communication tool and creation of SN in teenagers; (ii) knowing the degree of IntraA and InterA generated by the problematic use of the Internet; and (iii) defining the possible relationships between dependence, $C B$ and the levels of PA determined in an objective way through the use of accelerometers.

\section{METHODS}

\section{Design and Participants}

The present research is framed within the context of a non-experimental, descriptive and correlational crosssectional study.

Incidental sampling in secondary schools with 184 students. A specific sample of the study of 54 students ( $M$ $=14.26 ; S D=1.34$ ), to whom accelerometers are set to measure the PA levels.

\section{Instruments}

Adjustment of the Internet-Related Experiences Questionnaire (IREQ) (Casas et al., 2013) with $a=0.79$, whereas in the present research $a=0.81$. It consists of 12 items, Likert type scale, with marks ranging between 1-4 (where 1 means "nothing" and 4 means "quite") that reflect a frequency degree between "nothing" and "quite". The questionnaire measures two dimensions: (i) Intrapersonal conflict or dependence (IntraA). In this present research $a=0.71$, which includes variables such as "do you get angry or irritable 
when you get distracted while you are using WAPP or connected to any SN?", "how often do you stop doing the things you are doing in order to stay connected to a SN or WAPP for a longer period of time?"; and (ii) Interpersonal conflict or dependence (InterA). In the present research $a=0.69$, which includes elements such as "do you think life without SN or WAPP is boring, empty and sad?", "how often do you add new contacts of people you have met through the Internet or SN?" or "when anything happens to you, do you need to either upload it to your profile or write some commentaries in WAPP?"

The Spanish version of the European Cyberbullying Intervention Project Questionnaire (ECIPQ) (Del Rey et al., 2015) comprises 22 items, Likert type scale, with 5 options, with marks ranging between 0-4 (where 0 means "never" and 4 means "always"). It includes actions to describe behaviours performed or suffered such as bad words, threats, rumours exclusion or spreading, or identity theft, among others. They happen by means of an electronic device referred to a period within the last 12 months. Own validation $(\alpha=0.69)$.

ActiGraph GT3X accelerometers physical activity. Objective method of time slots determination that each subject devotes to the PA performance of low, moderate or high intensity.

\section{Procedure}

Previous to the execution of the research, the informed consent of the family and the authorisation of education centres are requested.

The questionnaires are conducted at the school centres in the presence of the questioner. Once they have been finished, the ActiGraph GT3X accelerometers are set. They are programmed and initialised in a synchronised way through the Actilife 6.0 program to be worn at the waist, above the iliac crest, for seven days (60-second epoch).

\section{Data analysis}

The descriptive analysis of the variables "use of communication applications" and "IntraA" and "InterA" is presented with frequencies, percentages, means, typical variances and modes.

Bivariate correlations are also applied delivering the Spearman correlation coefficient to test the level and the relationship direction among the different variables of the survey. The correlation level is established following the recommendations of the experts (Pulver et al., 1988).

In order to determine the levels of PA performance (i.e. low, moderate or high) used were, the cut points established by Eklund et al. (2004). The descriptive results of these variables are presented in the study by Corral-Pernía et al. (2018), belonging to the same work project. In the present work, they have been used in the correctional analysis together with the variables IntraA and InterA as well as Cyberagression (CyberA) and Cybervictimisation (CyberV).

We process the data by means of SPSS ${ }^{\circledR}$ version 24.0 (IBM Corp, Armonk, NY, USA) for Windows.

\section{RESULTS}

$96.3 \%$ of the survey respondents use Internet applications as a way of communication in $\mathrm{SN}$. Most of the young people often use two applications (57.4\%), followed by $29.6 \%$ who use only one and $93 \%$ who use three or more applications. Among the most utilised, the first option is WAPP (66.7\%), followed by Instagram and Snapchat (Table 1.) 
Table 1. Communication applications and SN used as 1st and 2nd option

\begin{tabular}{lcccc}
\hline & \multicolumn{2}{c}{ 1st option } & \multicolumn{2}{c}{ 2nd option } \\
\hline & Frequencies & $\%$ & Frequencies & $\%$ \\
\hline WhatsApp & 36 & 66.7 & 10 & 18.5 \\
Instagram & 15 & 27.8 & 21 & 38.9 \\
Snaptchat & 1 & 1.9 & 2 & 3.7 \\
Telegram & 0 & 0 & 1 & 1.9 \\
Twiter & 0 & 0 & 1 & 1.9 \\
Skyppe & 0 & 0 & 1 & 1.9 \\
None & 2 & 3.7 & 18 & 33.3 \\
Total & 54 & 100 & 54 & 100 \\
\hline
\end{tabular}

The global Internet addiction is $M=2.09(S D=0.53)$. There exists an IntraA of $M=2.21(S D=0.62)$ and an InterA of $M=1.97(S D=0.53)$.

Table 2. Intrapersonal and Interpersonal conflicts generated by the Internet use

\begin{tabular}{|c|c|c|c|c|c|}
\hline IntraA & Mean & Mode & InterA & Mean & Mode \\
\hline $\begin{array}{l}\text { When you have problems, } \\
\text { connecting to the SN or WAPP } \\
\text { helps you escape from them }\end{array}$ & 2.61 & 2 & $\begin{array}{l}\text { Life without the SN and WAPP } \\
\text { is boring, empty and sad }\end{array}$ & 1.91 & 1 \\
\hline $\begin{array}{l}\text { You continuously check your SN } \\
\text { and WAPP }\end{array}$ & 3.28 & 4 & $\begin{array}{l}\text { When you are connected to a } \\
\text { SN or use WAPP, you lose } \\
\text { track of time }\end{array}$ & 2.91 & 3 \\
\hline $\begin{array}{l}\text { You get angry or irritable when } \\
\text { you get distracted while you are } \\
\text { using WAPP or connected to a } \\
\text { SN }\end{array}$ & 1.87 & 1 & $\begin{array}{l}\text { It is easier or more comfortable } \\
\text { for you to relate to people } \\
\text { through a SN or WAPP than } \\
\text { face to face }\end{array}$ & 1.57 & 1 \\
\hline $\begin{array}{l}\text { Frequency of withdrawal of the } \\
\text { things you are doing to spend a } \\
\text { longer period of time connected } \\
\text { to a SN or WAPP }\end{array}$ & 2.0 & 2 & $\begin{array}{l}\text { Frequency with which you add } \\
\text { new contacts of people you } \\
\text { have met through the Internet } \\
\text { or SN }\end{array}$ & 2.31 & 2 \\
\hline $\begin{array}{l}\text { When you are not online or you } \\
\text { do not have your mobile phone to } \\
\text { check your WAPP or SN, you } \\
\text { feel unsettled or worried }\end{array}$ & 1.65 & 1 & $\begin{array}{l}\text { Your academic performance } \\
\text { has been negatively affected by } \\
\text { the use of WAPP or the SN }\end{array}$ & 1.63 & 1 \\
\hline $\begin{array}{l}\text { You get nervous and check your } \\
\text { mobile phone very often when it } \\
\text { has been a long time from the } \\
\text { moment you uplod a photo or } \\
\text { write a commentary until your } \\
\text { friends make some remarks }\end{array}$ & 1.87 & 1 & $\begin{array}{l}\text { When anything happens to you, } \\
\text { you need to either upload it to } \\
\text { your profile or write } \\
\text { commentaries in WAPP }\end{array}$ & 1.54 & 1 \\
\hline
\end{tabular}

Note: scale 1-4 (1 means "nothing" and 4 "quite") 
As it can be observed in Table 2, the use of SN or communication applications such as WAPP generates an IntraA that is translated into the need of continuously checking the SN and WAPP $(M=3.28 ; S D=0.96)$, the use of the Internet as a way of escaping from problems $(M=2.61 ; S D=0.99)$ and the withdrawal from other activities in order to be longer connected to the Internet $(M=2.0 ; S D=0.91)$.

The InterA produces alterations in behaviours such as the loss of track of time when the teenager is connected to the Internet or uses WAPP $(M=2.91 ; S D=0.89)$ as well as the fact of adding people met through the Internet or $S N$ as new contacts $(M=2.31 ; S D=1.02)$.

As an orientation (Table 3), and since there is no agreement on the assessment at which a behaviour is considered to be addictive, in IntraA $16.7 \%$ of the sample shows means within the range of the maximum values ("3"- "4"), whereas $50.1 \%$ shows mean within intermediate values ("2" up to "3"). In InterA, the means among the highest values are reached by $5.7 \%$ and the intermediate values by $48.3 \%$.

Table 3 Assessments distribution of intrapersonal and interpersonal addictions for the scores 1-2, 2-3, 3-4

\begin{tabular}{cccccc}
\hline & \multicolumn{2}{c}{ IntraA } & \multicolumn{3}{c}{ InterA } \\
\hline & \multicolumn{3}{c}{ \% scores } & & \multicolumn{3}{c}{$\%$ scores } \\
Mean & $\%$ & $(1-2,2-3,3-4)$ & Mean & $\%$ & $(1-2,2-3,3-4)$ \\
\hline 1.17 & 7.4 & 33.4 & 1.17 & 3.7 & 46.3 \\
1.50 & 13.0 & & 1.33 & 11.1 & \\
1.67 & 5.6 & & 1.50 & 14.8 & \\
1.83 & 7.4 & & 1.67 & 5.6 & \\
\hline 2.00 & 14.8 & 50.1 & 1.83 & 11.1 & \\
2.17 & 5.6 & & 2.00 & 18.5 & 48.3 \\
2.33 & 7.4 & & 2.17 & 9.3 & \\
2.50 & 7.4 & & 2.33 & 5.6 & \\
2.67 & 9.3 & & 2.50 & 5.6 & \\
2.83 & 5.6 & & 2.67 & 9.3 & \\
\hline 3.00 & 7.4 & 16.7 & 3.00 & 1.9 & \\
3.17 & 7.4 & & 3.17 & 1.9 & \\
3.67 & 1.9 & & 3.67 & 1.9 & \\
\hline Total & 100 & & & 100 & \\
\hline
\end{tabular}

A high percentage of the sample shows a potentially risk behaviour when using the Internet; for example, addiction issues or the appearance of other problems such as CB, cybergrooming or sexting, as it is described below in Table 4.

Considering the data about the high frequency of use (values " 3 " and "4"), the need of continuously checking the SN and WAPP is manifested by $75.9 \%$ of the simple, $70.4 \%$ losses the track of time when being online, $31.5 \%$ frequently adds as new contacts people they meet through the Internet or the $\mathrm{SN}$ (in this variable, only $20.4 \%$ states never adding as new contacts unknown people -value " 1 "-) and $22 \%$ stops doing other activities in order to be online for a longer period of time. 
Table 4. Behaviours which describe the Internet use by teenagers

\begin{tabular}{|c|c|c|c|c|}
\hline & $\begin{array}{c}\text { You continuously } \\
\text { check your SN and } \\
\text { WAPP }\end{array}$ & $\begin{array}{l}\text { Frequency of } \\
\text { withdrawal of the } \\
\text { things you are doing } \\
\text { to spend a longer } \\
\text { period of time } \\
\text { connected to a SN or } \\
\text { WAPP }\end{array}$ & $\begin{array}{l}\text { When you are } \\
\text { connected to a SN or } \\
\text { use WAPP, you lose } \\
\text { track of time }\end{array}$ & $\begin{array}{l}\text { Frequency with } \\
\text { which you add new } \\
\text { contacts of people } \\
\text { you have met } \\
\text { through the Internet } \\
\text { or SN }\end{array}$ \\
\hline (Nothing) 1 & 5.6 & 31.5 & 7.4 & 20.4 \\
\hline 2 & 18.5 & 46.3 & 22.2 & 48.1 \\
\hline 3 & 18.5 & 13.0 & 42.6 & 11.1 \\
\hline (Quite) 4 & 57.4 & 9.2 & 27.8 & 20.4 \\
\hline Total & $100 \%$ & $100 \%$ & $100 \%$ & $100 \%$ \\
\hline
\end{tabular}

Note: Values displayed in percentages

The correlational analysis shows a significant positive relation between IntraA and cybervictimisation (CyberV) $(r=0.305 ; p=0.025)$, between IntraA and cyberagression (CyberA) $(r=0.300 ; p=0.027)$, and between InterA and CyberA ( $r=0.328 ; p=0.015)$.

However, no correlation can be found between IntraA or InterA and the different levels of PA. Similarly, no correlation can be found between $\mathrm{CB}$ and the levels of PA, either.

Table 5. Relation between IntraA, InterA, CyberV, CyberA and levels of PA.

\begin{tabular}{lccccccc}
\hline & 1 & 2 & 3 & 4 & 5 & 6 & 7 \\
\hline 1.IntraA & 1.000 & $0.711^{* *}$ & $0.305^{*}$ & $0.300^{*}$ & -0.193 & -0.166 & -0.169 \\
2.InterA & $0.711^{* *}$ & 1.000 & 0.234 & $0.328^{*}$ & -0.080 & 0.009 & -0.138 \\
3.CyberV & $0.305^{*}$ & 0.234 & 1.000 & $0.483^{* *}$ & -0.159 & 0.013 & -0.092 \\
4.CyberA. & $0.300^{*}$ & $0.328^{*}$ & $0.483^{* *}$ & 1.000 & -0.070 & 0.141 & 0.072 \\
5. PA Light & -0.193 & -0.080 & -0.159 & -0.070 & 1.000 & $0.729^{* *}$ & $0.332^{*}$ \\
6. PA Moderate & -0.166 & 0.009 & 0.013 & 0.141 & $0.729^{* *}$ & 1.000 & $0.519^{* *}$ \\
7. PA Vigorous & -0.169 & -0.138 & -0.092 & 0.072 & $0.332^{*}$ & $0.519^{* *}$ & 1.000 \\
\hline Note Spearman's coefficient **p $<0.01 * \mathrm{p}<0.05$ & & & &
\end{tabular}

Note: Spearman's coefficient $* * \mathrm{p}<0.01 * \mathrm{p}<0.05$

\section{DISCUSSION}

Data obtained about the use of the Internet as a way of communication are very similar to those presented by the National Statistics Institute (INE, 2017) as well as by Sánchez and Otero (2010), close to 95\%. Nevertheless, they are slightly higher than those collected by the Childhood Observatory in Andalusia (Observatorio de la Infancia, 2010).

In this present research, intrapersonal conflicts caused by the Internet use are higher than interpersonal ones $(M=2.21$ and $M=1.97$, respectively). Such data do not coincide with the ones obtained by Casas et al. 
(2013) in which there are difficulties related to the use of the Internet reflected in interpersonal factors (IntraA $=1.77 ;$ InterA $=2.51)$ as well as in the study by Ortega-Ruiz et al. $(2012)$ with (2.45 and 1.90).

The global Internet addiction of 2.09 is very similar to the one obtained by both research quoted above (Casas et al., 2013 and Ortega-Ruiz et al., 2012, with 2.14 and 2.18 respectively), considered as worrying or prospectively at risk.

If the percentage of the sample with a higher frequency of occurrence of problematic behaviours in SN and WAPP-type applications is considered, (values " 3 ", "4") with $7.4 \%$ of the sample (16.7\% in IntraA and $5.7 \%$ in InterA), this is in accordance with results obtained by Carbonell et al. (2012), with a percentage of $8.2 \%$, lower to the ones obtained by Gómez et al. (2014) and Piguet et al. (2015), with 19.9\% and 13\% respectively, and on the contrary higher than 3.3\% that is the percentage obtained by Estévez et al. (2015). It must be kept in mind that it is difficult to make valid comparisons among the different studies since there is no coincidence in order to establish the cut-off points from which this can be defined an abusive Internet use according to Beranuy et al. (2009).

One of the riskiest behaviours that can be associated with the Internet use is making contact with unknown people (31.5\% frequently adds this kind of contacts). These are data very similar to those obtained by Helguera (2017) and Fernández-Montalvo et al. (2015).

Although in this present research neither the goal nor the effect of making contact with unknown people is analysed, it should be noted that Bringé and Sádaba (2011) state that 14\% of teenagers have arranged an appointment through this mean and that most of the studies show that these aspects are some of the most commonly related to the risk of CB (Garaigordobil, 2013; Kowalski et al., 2014; Modecki et al., 2014).

The relations between the Internet addiction and CB have also been proved by Kowalski et al. (2014), Bear et al. (2011) and Fernández and López (2015) who note as risk factors the frequency of Internet exposure, the revelation of personal data and the social relationships in the net. However, no study can be found which identifies the possible relation between Internet addictions and behaviours related to CyberA, which have indeed been observed in this work with the InterA.

Finally, it should be pointed out that there exists very few studies which analyse the relationship between a problematic Internet use, $\mathrm{CB}$ and $\mathrm{PA}$. In this present research no relation has been found among these variables, as opposed to Kim et al. (2015), where it is concluded that problematic users of mobile phones perform less PA, or Roman and Taylor (2013), who note a connection between victimisation and lower PA practice of at least for a period of 60 minutes a week. Nevertheless, there are indeed results which establish the fact of being more physically active by means of the involvement in sport activities as protective factor of victimisation and as decrease of the effects of $B$ (Driessens, 2015; Merril and Hanson, 2016).

\section{CONCLUSIONS}

As the first objective is concerned, it must be highlighted that the use of $\mathrm{SN}$ and communication applications is very high, since it is obtained that practically the totality of teenagers use the Internet with this aim.

With respect to "the level of Internet addiction", $50 \%$ of the sample $(M=2.01)$ shows a potentially risk use towards the development of addictive behaviours or towards suffering or committing any kind of cyberabuse, in this case more related to intrapersonal conflicts than to interpersonal ones. 
Concerning the third objective, "to know the possible relations among the variables dependence on the Internet, $C B$ and PA levels", it can be concluded that there exists indeed a relation between dependence on the Internet and $\mathrm{CB}$, between IntraA and CyberA and CyberV, and finally between InterA and CyberA. Nonetheless, there is no relation between dependence on the Internet and the levels of PA, or between $C B$ and PA.

In light of the results and the few existing studies, it would be necessary to increase the number of studies that analyse the effects of the problematic Internet use and the PA, this last variable measured both in an objective manner and by means of specific questionnaires. It would also be suitable to assess the relation among the above variables with inactivity, sedentariness and sleeping hours.

Moreover, and due to the impact of teenagers' behaviour with respect to the Internet use, SN and communication applications, it would be appropriate to expand the measures that are already being developed in some school centres (aimed at children, young people, families and teachers) with the purpose of educating about an adequate use of these tools.

\section{REFERENCES}

Antoniadou, N., Kokkinos, C.M., \& Markos, A. (2016). Possible common correlates between bullying and cyber-bullying among adolescents. Psicología Educativa, 22, 27-38. https://doi.org/10.1016/i.pse.2016.01.003

Aragón, M., Mendoza, E., \& Márquez, G. (2016). Ciberadicción: Una aproximación bajo la perspectiva de la ingeniería. Revista Iberoamericana de Producción Académica y Gestión Educativa, 4, 1-35.

Armstrong, L., Phillips, J. G., \& Saling, L. L. (2000). Potential determinants of heavier internet usage. International Journal of Human-Computer Studies, 53, 537-550. https://doi.org/10.1006/ijhc.2000.0400

Arora, T., Broglia, E., Thomas, GN., \& Taheri, S. (2014). Associations between specific technologies and adolescents sleep quanty, sleep quality, and parasomnias. Sleep medicine, 15(2), 240-247. https://doi.org/10.1016/.sleep.2013.08.799

Bear, George G., Clare Gaskins, Jessica Blank, and Fang Fang Chen. (2011). Delaware School Climate Survey-Student: Its Factor Structure, Concurrent Validity, and Reliability. Journal of School Psychology 49 (2): 157-74. https://doi.org/10.1016/j.jsp.2011.01.001

Beranuy, M., Chamarro, A., Graner, C., \& Carbonell, X. (2009). Validación de dos escalas breves para evaluar la adicción a Internet y el abuso de móvil. Psicothema, 21, 480-485.

Biolcati, R., Mancini, G., \& Trombini, E. (2018). Proneness to boredom and risk behaviors during adolescents' free time. Physological Reports, 121(2), 303-323. https://doi.org/10.1177/0033294117724447

Bringué, X., \& Sádaba, C. (2011). Menores y redes sociales. Madrid: Colección Foro Generaciones Interactivas/Fundación Telefónica.

Carbonell, X., Chamarro, A., Griffiths, M., Oberst, U. Cladellas, R., \& Talarn, A. (2012). Problematic internet and cell phone use in Spanish teenagers and young students. Anales de psicología, 28(2), 789-796. https://doi.org/10.6018/analesps.28.3.156061

Casas, J.A., Ruiz-Olivares, R., \& Ortega-Ruiz, R. (2013). Validation of internet and Social Networking Experiences Questionnaire in Spanish adolescents. International Journal of Clinical and Health Psychology, 13, 40-48. https://doi.org/10.1016/S1697-2600(13)70006-1

Chacón-Cuberos, R., Martínez-Martínez, A., Castro-Sánchez, M., Espejo-Gárces, T., Valdivia-Moral, P., \& Zurita-Ortega, F. (2015). Relación entre bullying, género y actividad física: estudio en escolares 
de la provincia de Granada. Trances: revista de transmisión de conocimiento educativo y de la salud, 7(6), 791-810.

Corral-Pernía, J.A., Del Rey, R., Domínguez-Gálvez, J.M., \& Chacón-Borrego, F. (2017, noviembre). El acoso escolar según el nivel de actividad física determinado por el PAQ-C. Póster presentado al I Congreso Internacional de Psicología, Salud y Educación, Oviedo, España.

Corral-Pernía, J.A., Chacón-Borrego, F., Fernández-Gavira, J., \& Del Rey, R. (2018). Bullying and cyberbullying according to moderate vigorous physical activity (MVPA) in Secondary School's Students. Journal of Sport Psychology, 27(S3), 70-75.

Del Rey, R., Casas, J.A., Ortega-Ruiz, R., Schultze-Krumbholz, A., Scheithauer, H., Smith, P., Thonson, F., Barkoukis, V., Tsorbatzoudis, H., Brigdi, A., Guarini, A., Pyzalski, J., \& Plichta, P. (2015). Structural validation and cross-cultural robust-ness of the European Cyberbullying Intervention Project Questionnaire. Computers in Human Behavior, 50, 141-147. https://doi.org/10.1016/i.chb.2015.03.065

Dinev, T., Hart, P., \& Mullen, M.R. (2008). Internet Privacy Concerns and Beliefs about Government Surveillance: An Empirical Investigation. Journal of Strategic Information Systems 17 (3): 214-33. https://doi.org/10.1016/i.jsis.2007.09.002

Driessens, C. M.E.F. (2015). Extracurricular activity participation moderates impact of family and school factors on adolescents' disruptive behavioural problems. BMC Public Health 15. https://doi.org/10.1186/s12889-015-2464-0

Echeburúa, E., \& Corral, P. (2010). Adicción a las nuevas tecnologías y a las redes sociales en jóvenes: un nuevo reto. Adicciones, 22, 91-96. https://doi.org/10.20882/adicciones.196

Ekelund, U., Sardinha, L.B., Anderssen, S., Harro, M., Franks, P.W., Brage, S., Cooper, A., Andersen, L.B., Riddoch, C., \& Froberg, K. (2004). Associations between objectively assessed physical activity and indicators of body fatness in 9 to 10 years old European children: a population-based study from 4 distinct regions in Europe (the European Youth Heart Study). Am. J. Clin. Nutr. 80(3), 584-590. https://doi.org/10.1093/ajcn/80.3.584

Estévez, L., Bayón, C., de la Cruz, J., \& Fernández-Liria, A. (2009). Uso y abuso de internet en adolescentes. En E. Echeburúa, F.J. Labrador y E. Becoña (eds.). Adicción a las nuevas tecnologías (pp. 101-130). Madrid: Pirámide.

Fernández, C.S., \& Lopez-Hernaez, L. (2015). Risk factors in ciberbullying. Frequency and exposition of personal data on the internet. Internatinal Journal of Sociology of Education, 4(1), 1-25. https://doi.org/10.4471/rise.2015.01

Fernández-Montalvo, J., Peñalba, A., \& Irazabal, I. (2015). Internet use habits and risk behaviours in preadolescence. Comunicar, 22(44), 113-121. https://doi.org/10.3916/C44-2015-12

Garaigordobil, M. (2013). Cyberbullying: prevalencia en el País Vasco, conexión con variables personales y familiares, y programas de prevención e intervención. Revista digital de la Asociación CONVIVES, 3, 45-46.

Garmendia, M., Garitaonandia, C., Martínez, G., \& Casado, M. A. (2011). Riesgos y seguridad en Internet: Los menores españoles en el contexto europeo. Universidad del País Vasco/Euskal Herriko Unibertsitatea, Bilbao: EU Kids Online.

Giménez, A.M., Luengo, J.A., \& Bartrina, M.J. (2017). What are young people doing on internet? Use of ICT, parental supervision strategies and exposure to risks. Electronic Journal of Research in Educational Psychology, 15(3), 533-552. https://doi.org/10.14204/eirep.43.16123

Gómez Mármol, A., Sánchez-Alcaraz Martínez, B., Valero Valenzuela, A., \& De la Cruz Sánchez, E. (2018). Perceived violence, sociomoral attitudes and behaviours in school contexts. Journal of Human Sport and Exercise, 13(1), 138-148. https://doi.org/10.14198/hhse.2018.131.14 
Gómez, P., Rial, A., Braña, T., Varela, J., \& Barreiro, C. (2014). Evaluation and early detection of problematic Internet use in adolescents. Psicothema, 26, 21-26. https://doi.org/10.7334/psicothema2013.109

Helguera, M. (2017). Las nuevas tecnologías de la información y comunicación. Infonova. Nuevas tecnologías y trastornos del comportamiento, 32, 17-28.

Hinduja, S., \& Patchin, J.W. (2009). Bullying Beyond the Schoolyard: Preventing and Responding to Cyberbullying. Thousand Oaks, CA: Corwin.

INE (2017). Encuesta sobre equipamiento y uso de tecnologías de la información y comunicación en los hogares. Madrid: INE. http://www.ine.es/jaxi/Datos.htm?path=/t25/p450/base_2011/a2017//0/\&file=01005.px

Kim, J., \& Lee, J. E. R. (2011). The facebook paths to happiness: Effects of the number of facebook friends and self-presentation on subjective well-being. Cyberpsychology, Behavior, and Social Networking, 14, 359-364. https://doi.org/10.1089/cyber.2010.0374

Kim, S.E., Kim, J.W., \& Jee, Y.S. (2015). Relationship between Smartphone addiction and physicla activity in Chinese international students in Korea. Journal of behavioral addictions, 4(3), 200-205. https://doi.org/10.1556/2006.4.2015.028

Kowalski, R. M., Giumetti, G. W., Schroeder, A. N., \& Lattanner, M. R. (2014). Bullying in the digital age: A critical review and meta-analysis of cyberbullying research among youth. Psychological Bulletin, 140, 1073-1137. https://doi.org/10.1037/a0035618

Labrador, F.J., \& Villadongos, S. (2010). Menores y nuevas tecnologías: conductas indicadoras de posible problema de adicción. Psicothema, 22(2), 180-188.

Merril, R. M. and Hanson, C. L. (2016). Risk and protective factors associated with being bullied on school property compared with cyberbullied. BMC Public Health, 16.

Modecki, K.L., Minchin, J., Harbaugh, A.G., Guerra, N.G., \& Runions, K.C. (2014). Bullying prevalence across contexts: A meta-analysis measuring cyber and traditional bullying. Journal of Adolescent Health, 55, 602 - 611. https://doi.org/10.1016/i.jadohealth.2014.06.007

Muñoz-Rivas, M. J., Fernández, L., \& Gámez-Guadix, M. (2010). Analysis of the indicators of pathological Internet use in Spanish university students.The Spanish Journal of Psychology, 13, 697-707. https://doi.org/10.1017/S1138741600002365

OBSERVATORIO DE LA INFANCIA EN ANDALUCIA (2010). Nuevas tecnologías en la infancia y adolescencia (2009). Granada. Consejería de Igualdad y Bienestar Social. Junta de Andalucía.

Ortega, R., Calmaestra, J., \& Mora-Merchán, J.A. (2008). Ciberbullying. International Journal of Psychology and Psychological Therapy, 8(2), 183-192.

Ortega-Ruiz, R., Del Rey, R., \& Casas, J.A. (2012). Knowing, Building and Living Together on Internet and Social Networking: The ConRed Cyberbullying Prevention Program. International Journal of Conflict and Violence, 6(2), 302-312).

Ortega, R., Del Rey, R., \& Casas, J.A. (2013). Redes sociales y cyberbullying: El proyecto ConRed. Revista digital de la Asociación CONVIVES, 3, 34-44.

Ortega-Ruiz, R., Del Rey, R., \& Casas, J.A. (2016). Evaluar el bullying y ciberbullying validación española del EBIP-Q y del ECIP-Q. Psicología Educativa, 22, 71-79. https://doi.org/10.1016/.jpse.2016.01.004

Ortega-Ruiz, R., \& Zych, I. (2016). La ciberconducta y la psicología educativa: retos y riesgos. Psicología Educativa, 22, 1-4. https://doi.org/10.1016/i.pse.2016.04.001

Pichel, R. (2014). El uso problemático de Internet entre los adolescentes: Estado de la cuestión y retos inmediatos. TFG Universidad de Santiago de Compostela.

Piguet, C., Berchtold, A., Akre, C., \& Suris, J.C. (2015). What keeps female problematic internet users busy online? European Journal of Pediatrics, 174(8), 1053-1059). https://doi.org/10.1007/s00431015-2503-y 
Pulver, A. E., Bartko, J. J., \& Carpenter, W. T. (1988). The power of analysis: statistical perspectives: part 1. Psychiatry Research, 23, 301-309. https://doi.org/10.1016/0165-1781(88)90020-0

Roman, C. G. and Taylor, C. J. (2013). A multilevel assessment of school climate, bullying victimization, and physical activity. Journal of School Health, 83, 400-407. https://doi.org/10.1111/josh.12043

Sáchez-Martínez, M., \& Otero, A. (2009). Factors associated with cell phone use in adolescents in the comunity of Madrid (Spain). Cyberpsychology and Behavior, 12(2), 131-137. https://doi.org/10.1089/cpb.2008.0164

Tokunaga, R. S. (2010). Following you home from school: A critical review and synthesis of research on cyberbullying victimization. Computers in Human Behavior, 26, 277-287. https://doi.org/10.1016/j.chb.2009.11.014

Tsai, C. C., \& Lin, S. S. J. (2003). Internet addiction of adolescents in Taiwan: An interview study. CyberPsychology \& Behavior, 6,649-652. https://doi.org/10.1089/109493103322725432

Tsitsika, A., Janikian, M., Wójcik, S., Makaruk, K., Tzavela, E., Tzavara, C., Greydanus, D.,Merrick, J., \& Richardson, C. (2015). Cyberbullying victimization prevalence and associations with internalizing and externalizing problems among adolescents in six European countries. Computers in Human Behavior, 51, 1-7. https://doi.org/10.1016/i.chb.2015.04.048

Ybarra, M.L., \& Mitchell, K.J. (2004). Youth engaging in online harassment: associations with caregiverchild relationships, Interent use, and personal characteristics. J Adolesc., 27(3), 319-336. https://doi.org/10.1016/j.adolescence.2004.03.007

Zurita, F., Castro, M., \& Chacón, R. (2018). Análisis de la influencia de la modalidad deportiva sobre la victimización en escolares de Primaria. Educación, Sport, Health and Physical Activity, 2(1), 2-15. http://hdl.handle.net/10481/48262

Zych, I., Ortega-Ruiz, R., \& Del Rey, R. (2015). Systematic review of theoretical studies on bullying and cyberbullying: Facts, knowledge, prevention and intervention. Aggression and Violent Behavior, 23, 1-21. https://doi.org/10.1016/j.avb.2015.10.001

\section{@)}

This title is licensed under a Creative Commons Attribution-NonCommercial-NoDerivs 4.0 Unported License. 